\title{
PARASITES, DIET AND STABLE ISOTOPES OF SHORTHORN SCULPIN (MYOXOCEPHALUS SCORPIUS) FROM FrobISHER BAY, CANADA
}

\author{
DICK T.*, CHAMBERS C.* \& GALLAGHER C.P.****
}

\section{Summary:}

Shorthorn sculpin (Myoxocephalus scorpius) from Frobisher Bay, Baffin Island, is a slow growing long-lived species. A wide range of diet items were present in the stomachs of the shorthorn sculpins sampled but 2-3 diet items (amphipod species) comprised $99.5 \%$ of total food consumed. These amphipods were present in the stomachs in similar proportions among all age classes of shorthorn sculpin. Several new host records for parasites were reported and mean numbers of parasite species increased with shorthorn sculpin age. The increased diversity of parasite species and higher $\delta^{15} \mathrm{~N}$ values in older/larger individuals suggest that their diets were more diverse and the prey items consumed had higher $\delta^{15} \mathrm{~N}$ values. By contrast, the value of $\delta^{13} \mathrm{C}$ in dominant diet items masked the $\delta^{13} \mathrm{C}$ values of minor diet items. We conclude that parasites and stable isotope values provide complementary data on feeding patterns of the shorthorn sculpin. The ubiquitous marine acanthocephalan, Echinorhynchus gadi, was found at high prevalences (87-100\%) and mean intensities (28-35), and were localized in the midgut. In contrast to other studies on acanthocephalans, E. gadi did not influence fish condition as measured by condition factor, liver somatic and gonado-somatic indices.

KEY WORDS : shorthorn sculpin, Myoxocephalus scorpius, parasites, diet, stable isotopes.
Résumé : Parasitisme, RÉgime alimentaire et isOtOPES STABLES DU CHABOISSEAU À ÉPINES COURTES (MYOXOCEPHALUS SCORPIUS) DE LA BAIE DE Frobisher, CANADA

Le chaboisseau à épines courtes (Myoxocephalus scorpius) de la Baie de Frobisher, Terre de Baffin, est un poisson à croissance lente et de grande longévité. Une grande variété de proies alimentaires a été retrouvée dans l'estomac de nos échantillons mais 2 à 3 d'entreelles (des amphipodes) représentent 99,5\% des aliments consommés. Ces crustacés sont présents dans les mêmes proportions dans les estomacs des différentes classes d'âge de chaboisseau. Plusieurs espèces de parasites sont nouvellement rapportées chez ces poissons chez qui le nombre moyen des espèces de parasites augmente avec l'âge. La plus grande diversité d'espèces de parasites et des valeurs $\delta^{15} \mathrm{~N}$ plus élevées observées chez les individus plus vieux/plus grands suggère que leur régime alimentaire est soit plus diversifié et que les proies consommées ont des valeurs $\delta^{15} \mathrm{~N}$ plus élevées. De façon contrastée, les valeurs $\delta^{13} \mathrm{C}$ des proies dominantes du régime masquent les valeurs $\delta^{13} \mathrm{C}$ des proies secondaires. Nous concluons que le parasitisme et les valeurs d'isotopes stables apportent des données complémentaires sur l'alimentation de ce chaboisseau. Echinorhynchus gadi, acanthocéphale marin omniprésent, a été retrouvé à une fréquence élevée (87-100\%) et des intensités moyennes (28-35), et a été localisé dans l'intestin moyen. Contrairement à d'autres études sur les acanthocéphales, E. gadi n'a pas d'influence sur la condition et les indices gonado- et hépato-somatiques des poissons

MOTS CLÉS : chaboisseau à épines courtes, Myoxocephalus scorpius, parasitisme, régime alimentaire, isotopes stables.

Scott, 1988; Sulgostowska et al., 1990). From the limited information on shorthorn sculpin food habits, its diet is fairly broad (Moore \& Moore, 1974) and Norderhaug et al. (2005) described them as generalist, feeding on a wide range of kelp-associated invertebrates. Scott \& Scott (1988) listed some of the earliest records of parasites infecting sculpin in North America \& Sulgostowska et al. (1990) listed parasites from shorthorn sculpin collected in the Baltic Sea. Macdonald \& Margolis (1995) provided an extensive list of parasites from shorthorn sculpin but most were reported from the Atlantic region and most were protozoa and myxozoa. The metazoan parasite species listed included five non-host specific trematode species, one larval nematode, one larval tapeworm and the Mongenea, Gryodactylus groenlandicus Levisen 1881. Recently there has been an interest in the shorthorn sculpin as an intermediate host for the transmission of the seal worm, Pseudoterranova

* Department of Biological Sciences, University of Manitoba, Winnipeg, Manitoba, Canada, R3T 2N2.

** Current address: Fisheries and Oceans Canada, Winnipeg, Manitoba, Canada. 501 University Crescent, R3T-2N6.

Correspondence: Terry Dick. E-mail: tadick@cc.umanitoba.ca 
decipiens (Krabbe, 1878), (Jensen \& Andersen, 1992; Jensen, 1997; Midtgaard et al., 2003). There are no studies that focused on the Canadian Arctic or the relationship of diet, parasites transmitted through the diet and stable isotopes in fish muscle.

Sculpin species may be a good indicator for changes in the Arctic environment since they lack a swim bladder which limits their movements. Inshore populations of shorthorn sculpin likely feed on invertebrates that transmit common non-host specific marine parasites but little has been published on this relationship. Historical records of food consumed over time are commonly studied using stable isotopes ratios (Michener \& Kaufman, 2007) and it has become an important research tool to describe trophic relationships within freshwater (Johnson et al., 2004) and marine environments (Davenport \& Bax, 2002). Data from stable isotope analysis provides a measure of the assimilated diet, in the long term (Thomas \& Cahoon, 1993; Wainright et al., 1993; Post, 2002). The two most frequently studied natural isotopes are carbon $\left(\delta^{13} \mathrm{C}\right)$ and nitrogen $\left(\delta^{15} \mathrm{~N}\right)$ and these isotopes are useful in the construction of food webs as animals are similar in isotopic composition to their diets (Kline et al., 1998; Monteiro et al., 1991; Post, 2002; Sholto-Douglas et al., 1991). The level of nitrogen is usually enriched over the prey (diet item) because lighter ${ }^{14} \mathrm{~N}$ is excreted during transamination and deamination (Macko et al., 1982). By contrast, the fractionation of ${ }^{13} \mathrm{C}$ is usually less than nitrogen but it is useful to reveal the origin of the carbon source in the diet. (Minagawa \& Wada, 1984). Similar to stable isotopes, parasites provide an important proxy for diet as endohelminthes are transmitted in the diet. Stable isotopes of adult fish can reveal diet information for $>1$ year while parasites reveal diet (the intermediate host) for at least one year. Both types of data complement diet analysis which is limited by empty stomachs or variation in food availability across size ranges and life stages (Pinnegar \& Polunin 2000). The purpose of this study was to investigate diet, parasite infections, and $\delta^{13} \mathrm{C}$ and $\delta^{15} \mathrm{~N}$ stable isotopes among age classes of shorthorn sculpin from Frobisher Bay, Canada. These data would be used to provide additional information on the diet of short horn sculpin, using short-term (parasites transmitted by food) and long-term (stable isotopes of $\delta^{13} \mathrm{C}$ and $\delta^{15} \mathrm{~N}$ ) indicators.

\section{METHODS}

\section{STUDY AREA}

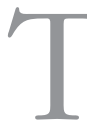

The sample sites were at the north end of Frobisher Bay, Baffin Island close to the community of Iqaluit. Site one was at Peterhead Inlet $\left(63^{\circ} 46^{\prime} \mathrm{N}, 68^{\circ} 42^{\prime} \mathrm{W}\right)$, west of Iqaluit, and site two, about $10 \mathrm{~km}$ east, was close to Iqaluit at the Sylvia Grinnell River estuary $\left(63^{\circ} 43^{\prime} \mathrm{N}, 68^{\circ} 46^{\prime} \mathrm{W}\right)$.

\section{SAMPLE COLLECTION}

Shorthorn sculpin were collected in early July 2002 from the Sylvia Grinnell estuary $(\mathrm{n}=21)$ and mid September 2005 from Peterhead Inlet $(n=80)$. Specimens were collected in the intertidal zone (approximate maximum intertidal range of $11.2 \mathrm{~m}$ ) from intertidal pools (typically along concave depressions at the base of a glacial erratic). Experimental gillnets (38, 64, 89, 114 and $139 \mathrm{~mm}$ stretched mesh) set and lifted at low tide (approximately 12 hours) were used.

All specimens were frozen shortly after capture for later examination. Fish were thawed, measured, weighed and eviscerated. The sex was recorded from each sample. Otoliths were collected and subsequently fish ages were determined by the "crack-and-burn" method described in CARE (2006).

\section{PARASITES}

The following organs were examined for parasites: esophagus, stomach, intestine divided into fore-, mid- and hind-gut, liver, spleen and body cavity. Parasite prevalence, mean intensity and abundance for parasites were calculated according to Margolis et al. (1982).

\section{DIET}

Food items from the stomach and the intestine were identified and counted. Diet data was analyzed as follows: percent frequency (number of a specific diet item divided by the total number of all diet items) and frequency of occurrence (\% individuals with a specific diet item) (Cortés, 1997).

\section{STABLE ISOTOPES}

$\delta^{13} \mathrm{C}$ and $\delta^{15} \mathrm{~N}$ isotopic analyses on the muscle (protein) were accomplished by continuous flow ion ratio mass spectrometry (CF-IRMS) using a GV-Instruments ${ }^{\circledR}$ IsoPrime attached to a peripheral temperature controlled EuroVector ${ }^{\circledR}$ elemental analyzer (EA) (University of Winnipeg Isotope Laboratory, UWIL). One mg samples of freeze dried fish muscle were loaded into tin capsules and placed in the EA auto-sampler in accompaniment with internally calibrated carbon/nitrogen standards [Pharma and Casein proteins: $\delta^{13} \mathrm{C}=-22.95 \%$ and $-26.98 \%$ Vienna PeeDee Belemnite (VPDB); $\delta^{15} \mathrm{~N}=$ $5.00 \% 0$ and $5.94 \%$ air, respectively].

Carbon and nitrogen isotope results are expressed using standard delta $(\delta)$ notation in units per mil (\%0). The delta values of carbon $\left(\delta^{13} \mathrm{C}_{\text {cell }}\right)$ and nitrogen $\left(\delta^{15} \mathrm{~N}_{\text {cell }}\right)$ represent deviations from a standard, such that:

$$
\delta_{\text {sample }}=\left[\left(\mathrm{R}_{\text {sample }} / \mathrm{R}_{\text {standard }}\right)-1\right] \times 10^{3}
$$


where $\mathrm{R}$ is the ${ }^{13} \mathrm{C} /{ }^{12} \mathrm{C}$ or ${ }^{15} \mathrm{~N} /{ }^{14} \mathrm{~N}$ ratio in the sample and the standard. The standards used for carbon and nitrogen isotopic analyses are VPDB and IAEA-N-1 (IAEA, Vienna), respectively.

Analytical precision, determined from the analysis of duplicate samples, was $\pm 0.16 \%$ for $\delta^{13} \mathrm{C}$ and $\pm 0.18 \%$ for $\delta^{15} \mathrm{~N}$. Accuracy was obtained through the analysis of laboratory standards used for calibration of results.

\section{DATA ANALYSIS}

Fulton's condition factor (Ricker 1975) was calculated for each fish (weight/length ${ }^{3}$ ) and Spearman's correlation coefficient was used to determine if there was a relationship with parasite burden. The gonad and liver somatic index, GSI and LSI, respectively, were also calculated for each fish (gonad or liver weight/total weight $\times 100$ ), to determine if there were correlations with parasite burden. A Kruskall Wallis test was used to determine if there was a difference in the mean size of $E$. gadi among the foregut, midgut and hindgut. A Bonferonni correction was then applied to conduct pairwise comparisons using the Mann Whitney test.

\section{RESULTS}

\section{SAMPLE CHARACTERISTICS}

Wwenty-one samples were collected from the Sylvia Grinnell estuary and 80 were collected from Peterhead Inlet. The range of ages in the samples was 2-19 years for females and 1-15 years for males. Females were generally larger than males, with the largest female and male equal to $277 \mathrm{~mm}$ and $259 \mathrm{~mm}$, respectively.

\section{DIET}

Diet items recovered from shorthorn sculpin are presented in Table I as percent frequency. The three most common food items were the amphipods: Gammarus setosus Dementieva, 1931, Onisimus litoralis (Kroyer, 1845) and O. edwardsii (Kroyer, 1846). Frequency of occurrence took into account the number of individual diet items /individual fish and ranking of diet items from sculpin collected at Peterhead Inlet was G. setosus, O. litoralis and Gammarus spp. Similarily, for the Sylvia Grinnell shorthorn sculpin sample, the ranking of the three most important diet items were different between the percent frequency and frequency of occurrence. The most abundant diet by percent frequency and frequency of occurrence were G. setosus, O. litoralis and O. edwardsii. Overall, G. setosus and Onisimus spp. were the most important diet items, comprising $99.5 \%$ of the total percent frequency of food consumed by the shorthorn sculpin from Peterhead Inlet and comprising $97.3 \%$ of the total percent frequency of food consumed by shorthorn sculpin from the Sylvia Grinnell estuary.

With exception of $G$. setosus and O. litoralis, which were evenly distributed, the remaining diet items were examined among equally distributed age classes: 1-4, 5-8, 9-12 and 13+ years. Age class 1-4 years were juveniles. The mean proportion, expressed as percent, of diet items in the stomach samples of shorthorn sculpin was calculated for the age classes of shorthorn sculpin. The average proportion of G. setosus, O. litoralis and

\begin{tabular}{|c|c|c|c|c|}
\hline \multirow[b]{2}{*}{ Food item } & \multicolumn{2}{|c|}{ Peterhead Inlet $(\mathbf{n}=\mathbf{8 0})$} & \multicolumn{2}{|c|}{ Sylvia Grinnell $(\mathrm{n}=21)$} \\
\hline & $\begin{array}{c}\text { Percent } \\
\text { frequency }\end{array}$ & $\begin{array}{c}\text { Frequency } \\
\text { of occurence }\end{array}$ & $\begin{array}{l}\text { Percent } \\
\text { frequency }\end{array}$ & $\begin{array}{c}\text { Frequency } \\
\text { of occurence }\end{array}$ \\
\hline \multicolumn{5}{|l|}{ Amphipoda } \\
\hline Gammaracathus relictus & 0 & 0 & 1.23 & 19.0 \\
\hline Gammarus setosus & 63.97 & 70.0 & 35.95 & 71.4 \\
\hline Gammarus spp. & 1.08 & 11.3 & 0 & 0 \\
\hline Themisto libellula & 0.09 & 3.8 & 0 & 0 \\
\hline Onisimus edwardsii & 4.52 & 7.5 & 33.50 & 23.8 \\
\hline Onisimus litoralis & 29.98 & 52.5 & 27.85 & 28.6 \\
\hline \multicolumn{5}{|l|}{ Copepoda } \\
\hline Calanus hyperboreus & 0.11 & 3.8 & 0 & 0 \\
\hline \multicolumn{5}{|l|}{ Gastropoda } \\
\hline Gastropoda spp. & 0.23 & 2.5 & 0 & 0 \\
\hline \multicolumn{5}{|l|}{ Malacostraca } \\
\hline Mysis oculata & 0 & 0 & 0.61 & 14.3 \\
\hline \multicolumn{5}{|l|}{ Polychaeta } \\
\hline Polychaete & 0 & 0 & 0.74 & 23.8 \\
\hline \multicolumn{5}{|l|}{ Actinopterygii } \\
\hline Boreogadus saida & 0.03 & 1.3 & 0.12 & 4.8 \\
\hline
\end{tabular}

Table I. - Total percent frequency (\%) and frequency of occurrence (\%) of diet items in $M$. scorpius sampled from Peterhead Inlet and the Sylvia Grinnell River estuary, Nunavut. 


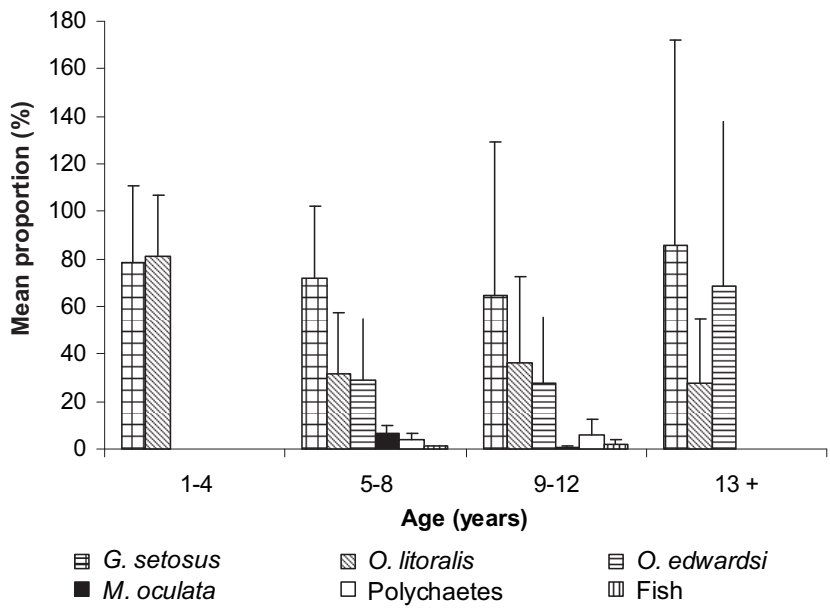

Fig. 1. - Mean and standard deviation of the proportion (\%) of amphipod diet items (Gammarus setosus, Onisimus litoralis and O. edwardsi) and diet items with high $\delta^{15} \mathrm{~N}$ signatures (Mysis oculata, polychaetes and fish) among age classes of shorthorn sculpin from Peterhead Inlet and the Sylvia Grinnell River estuary, Nunavut. Note absence of fish in the diet is likely due to the small sample size $(n=6)$ of sculpin $>13+$ years.

O. edwardsii, the most abundant items from both sites, were plotted against age classes (Fig. 1). The mean proportion of $G$. setosus remains relatively consistent among age classes (64.7-86.0 \%) although greater variability is observed among fish $>9-12$ years. The proportion of $O$. litoralis (81\%) in the diet is similar to G. setosus (78.7\%) among 1-4 year olds and decreases among older fish. O. edwardsii was not detected in 1-4-year-old fish and was detected in relatively low proportions, similar to O. litoralis, in 5-8 and 9-12 yearold shorthorn sculpin with increased occurrences among the $13+$ age classes. Copepods were only detected in $1-4$ year-old fish in an average proportion of $26.1 \%$. Gastropods and Boreogadus saida (Lepechin, 1774) were only found in 5-8 year-old samples and comprised an average of $4.9 \%$ and $1 \%$, respectively, of diet items. Mysis oculata (Fabricus, 1780) comprised an average of $6.9 \%$ and $0.9 \%$ of diet items in 5-8 and 9-12 year old fish, respectively, while polychaetes averaged $3.7 \%$ and $6.2 \%$ of diet items in 5-8 and 9-12 year old shorthorn sculpin, respectively (Fig. 1). Unidentifiable fish remains comprised an average of $1.9 \%$ of diet items in fish $13+$ years of age.

\section{PARASITES}

The most abundant parasite species recovered from shorthorn sculpin from Peterhead Inlet were the nematode, Capillaria sp., the acanthocephalan Echinorbynchus gadi Zoega in O.F. Muller 1776 and the trematode, Prosorbynchus squamatus Odhner, 1905 (Table II). Abundance values for the Cestoda sp. plerocercoids were similar to $P$. squamatus. Similar results were found for the Sylvia Grinnell estuary samples although Cestoda sp. were infrequent. Abundance values were low for the larval ascarid nematodes i.e., Pseudoterranovasp. from Peterhead Inlet samples and Anisakis sp. from the Sylvia Grinnell estuary samples. Two other parasite species, Derogenes varicus (O.F. Muller) Looss 1901 and

\begin{tabular}{|c|c|c|c|c|c|c|}
\hline \multirow[b]{2}{*}{ Parasite } & \multicolumn{3}{|c|}{ Peterhead Inlet $(\mathbf{n}=\mathbf{8 0})$} & \multicolumn{3}{|c|}{ Sylvia Grinnell estuary $(n=21)$} \\
\hline & $\begin{array}{c}\text { Pre- } \\
\text { valence }\end{array}$ & Mean intensity & Abundance & $\begin{array}{c}\text { Pre- } \\
\text { valence }\end{array}$ & Mean intensity & Abundance \\
\hline Brachyphallus crenatus & 5.0 & $2.75 \pm 2.22(0-6)$ & $0.14 \pm 0.74$ & 0 & $0 \pm 0$ & $0 \pm 0$ \\
\hline Derogenes varicus & 48.8 & $2.51 \pm 1.86(0-8)$ & $1.23 \pm 1.81$ & 81.0 & $4.53 \pm 6.04(0-23)$ & $3.67 \pm 5.70$ \\
\hline Lepidapedon rachion & 1.3 & $2.00 \pm 0.0(0-2)$ & $0.03 \pm 0.22$ & 0 & $0 \pm 0$ & $0 \pm 0$ \\
\hline Hemiuridae sp. & 2.5 & $1.50 \pm 0.71(0-2)$ & $0.04 \pm 0.25$ & 0 & $0 \pm 0$ & $0 \pm 0$ \\
\hline Podocotyle sp. larvae & 1.3 & $2.00 \pm 0.0(0-2)$ & $0.03 \pm 0.22$ & 0 & $0 \pm 0$ & $0 \pm 0$ \\
\hline Podocotyle atomon & 8.8 & $3.43 \pm 2.76(0-8)$ & $0.30 \pm 1.24$ & 0 & $0 \pm 0$ & $0 \pm 0$ \\
\hline Prosorbynchus squamatus & 62.5 & $10.48 \pm 15.66(0-65)$ & $6.55 \pm 13.35$ & 52.4 & $51.55 \pm 54.98(0-159)$ & $27.0 \pm 46.98$ \\
\hline $\begin{array}{l}\text { Prosorbynchus squamatus } \\
\text { larvae }\end{array}$ & 26.3 & $3.86 \pm 2.74(0-12)$ & $1.01 \pm 2.20$ & 23.8 & $6.40 \pm 6.31(0-17)$ & $1.52 \pm 3.97$ \\
\hline Unknown trematoda sp. & 1.3 & $1.00 \pm 0.0(0-1)$ & $0.01 \pm 0.11$ & 0 & $0 \pm 0$ & $0 \pm 0$ \\
\hline Trematoda sp. larvae & 1.3 & $5.00 \pm 0.0(0-5)$ & $0.06 \pm 0.60$ & 0 & $0 \pm 0$ & $0 \pm 0$ \\
\hline Bothrimonus sturionus & 25.0 & $2.40 \pm 2.76(0-10)$ & $0.60 \pm 1.71$ & 0 & $0 \pm 0$ & $0 \pm 0$ \\
\hline Cestoda sp. plerocercoid & 33.8 & $19.70 \pm 24.07(0-105)$ & $6.65 \pm 16.69$ & 4.8 & $7.0 \pm 0$ & $0.33 \pm 1.53$ \\
\hline $\begin{array}{l}\text { Pseudoterranova decipiens } \\
\text { larvae* }\end{array}$ & 25.0 & $3.70 \pm 2.60(0-10)$ & $0.93 \pm 2.05$ & 0 & $0 \pm 0$ & $0 \pm 0$ \\
\hline Capillaria sp. & 91.3 & $98.18 \pm 126.14(0-499)$ & $89.59 \pm 123.62$ & 100 & $111.86 \pm 89.25(7-336)$ & $111.86 \pm 89.25$ \\
\hline $\begin{array}{l}\text { Corynosoma strumosum } \\
\text { larvae }\end{array}$ & 13.8 & $2.08 \pm 1.08(0-4)$ & $0.31 \pm 0.85$ & 0 & $0 \pm 0$ & $0 \pm 0$ \\
\hline Echinorbynchus gadi & 87.5 & $34.71 \pm 40.25(0-140)$ & $30.38 \pm 39.36$ & 100 & $28.33 \pm 20.48(0-67)$ & $28.33 \pm 20.48$ \\
\hline Anisakis sp. larvae & 0 & $0 \pm 0$ & $0 \pm 0$ & 19.0 & $1 \pm 0$ & $0.19 \pm 0.40$ \\
\hline
\end{tabular}

$* \mathrm{n}=7$

Table II. - Prevalence (\%), mean intensity ( \pm SD), with range in brackets, and abundance ( \pm SD) of parasites in M. scorpius sampled from Peterhead Inlet and the Sylvia Grinnell River estuary, Nunavut. 
a cestode plerocercoid, were found in low numbers in shorthorn sculpin from both sample sites (Table II). The average number of parasite species increased with shorthorn sculpin age (Fig. 2). Shorthorn sculpin 1-4 years of age had an average of 3.2 parasites which increased to 4.8 parasites in 5-8 year-olds, 5.3 in 9-12 year-olds and 5.8 parasites in $13+$ year old sculpin. Parasites species recovered from sculpin $>5$ years included Anisakis sp., Bothrimonas sturionis Duvernoy 1842, $P$. decipiens larvae and Podocotyle atomon (Rudolphi, 1802) Ohhner, 1905. Parasites species recovered from most age classes included Cestode sp., Prosorbynchus larvae, P. squamatus, D. varicus, Capillaria sp. and E. gadi.

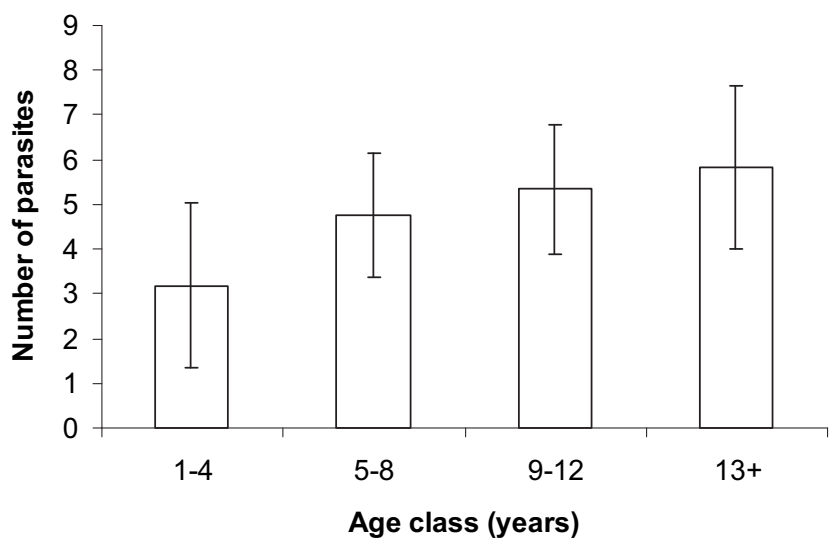

Fig. 2. - Mean number ( \pm 1 standard deviation) of parasite species plotted against age of shorthorn sculpin from Peterhead Inlet and the Sylvia Grinnell estuary, Nunavut.

Echinorhynchus gadi, a common parasite of marine fishes, had prevalences of $87.5 \%$ and $100 \%$ and mean intensities of 34.71 and 28.33 in samples from Peterhead Inlet and Sylvia Grinnell River, respectively (Table II). The median size of $E$. gadi differed along the gut $\mathrm{H}(2)=$ 33.7, $\mathrm{p}<0.01$ as well as the median number $X^{2}(2)=$ 15.1, $\mathrm{p}<0.01$ (Fig. 3). There were no size differences between the worms in the foregut and midgut U(6109.5), $p>0.05$, however, worms differed in size between the hindgut and the midgut $\mathrm{U}(11943), \mathrm{p}<0.01$, and hindgut and foregut $\mathrm{U}(614), \mathrm{p}<0.01$. Most worms (85.1\%) were found in the midgut and relatively few worms were recovered from the fore- and hindgut (Fig. 3). No evidence of pathology resulting from attachment was noted even when $E$. gadi was present in numbers as high as 139. E. gadi abundance was positively correlated with condition factor, LSI, GSI and length for females (Table III). Male LSI was negatively correlated with $E$. gadi abundance while condition, GSI and length were positively correlated (Table III). E. gadi numbers increased with host size (Fig. 4).

Capillaria sp. was found in Gammarus spp. and Onisimus spp. specimens from the stomach contents of shorthorn sculpin.

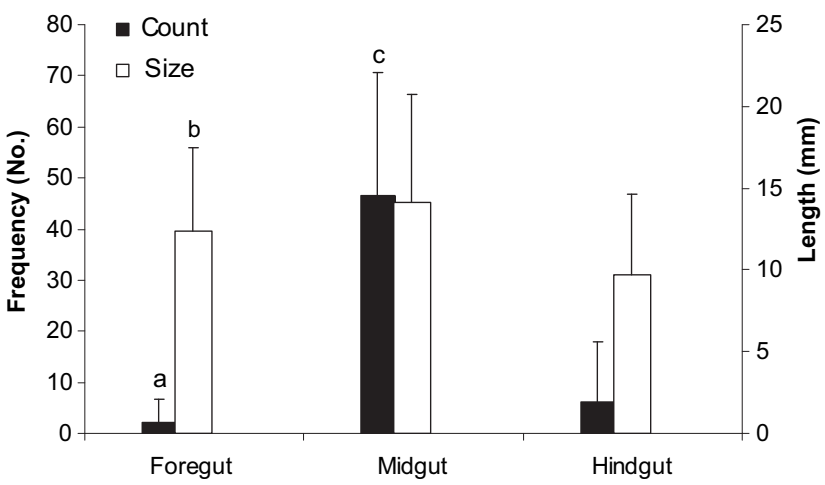

Fig. 3. - Mean number and length (mm) ( $\pm 1 \mathrm{SD})$ of Echinorhynchus gadi in the foregut, midgut and hindgut of shorthorn sculpin from Peterhead Inlet and the Sylvia Grinnell River estuary, Nunavut. $\mathrm{a}=$ statistically significant differences between foregut, midgut and hindgut $(\mathrm{p}<0.05)$; $\mathrm{b}=$ no significant differences between foregut and midgut, significant differences between foregut and hindgut $(\mathrm{p}>0.05) ; \mathrm{c}=$ significant differences between midgut and hindgut $(\mathrm{p}<0.05)$.

\begin{tabular}{lrc}
\hline & Male & Female \\
\hline Condition & 0.44 & 0.56 \\
LSI & 0.13 & 0.53 \\
GSI & 0.44 & 0.72 \\
Length & 0.79 & 0.61 \\
\hline
\end{tabular}

* all p-values were equal to 0.001 .

Table III. - Spearman correlation coefficient* of E. gadi abundance and condition factor, LSI, GSI and length of male and female $M$. scorpius sampled from Peterhead Inlet and the Sylvia Grinnell River estuary, Nunavut.

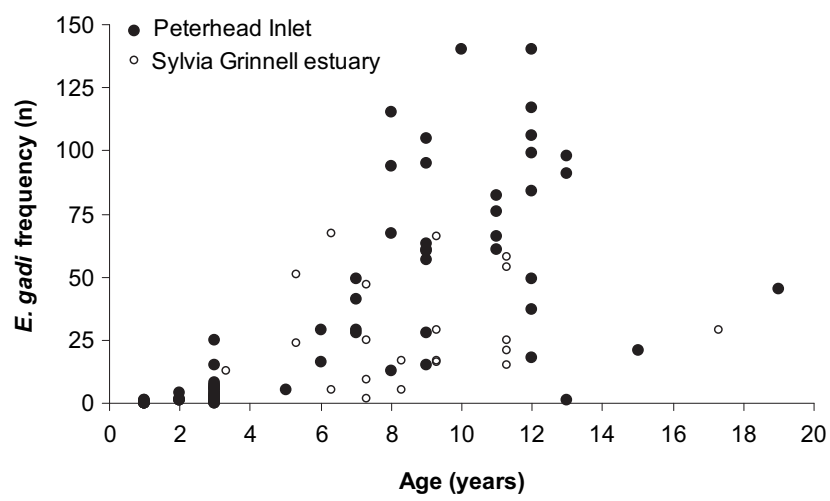

Fig. 4. - Relationship between frequency of Echinorbynchus gadi and age of shorthorn sculpin from Peterhead Inlet and the Sylvia Grinnell River estuary, Nunavut.

\section{STABLE ISOTOPES}

Stable isotope data was determined for four samples from the Sylvia Grinnell estuary and 42 samples from Peterhead Inlet. $\delta^{15} \mathrm{~N}$ ranged from 12.70 to $17.21 \%$ while $\delta^{13} \mathrm{C}$ ranged from -19.71 to $-16.21 \%$ (Fig. 5). A plot of $\delta^{15} \mathrm{~N}$ values against age classes of shorthorn sculpin showed an increase from age 2 to 15 years. A 


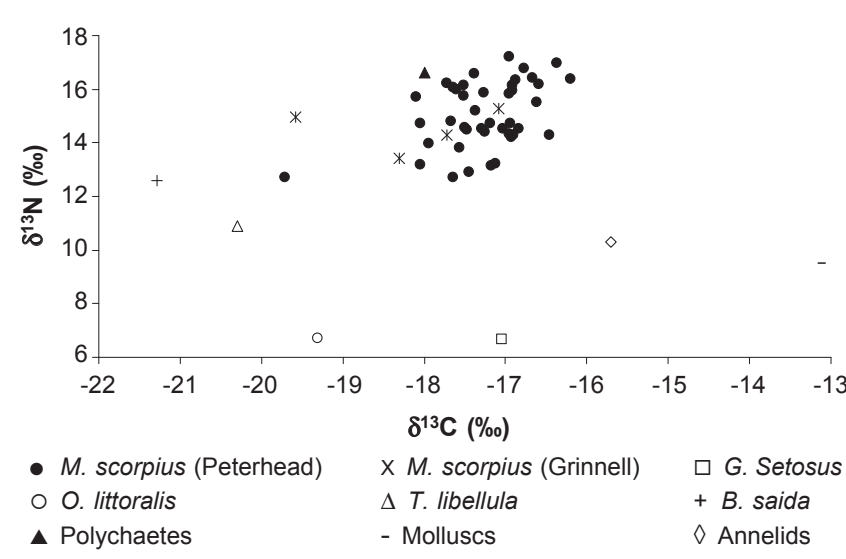

Fig. 5. - Carbon and nitrogen stable isotope values of Myoxocephalus scorpius and diet items collected from Peterhead Inlet and the estuary of the Sylvia Grinnel River.

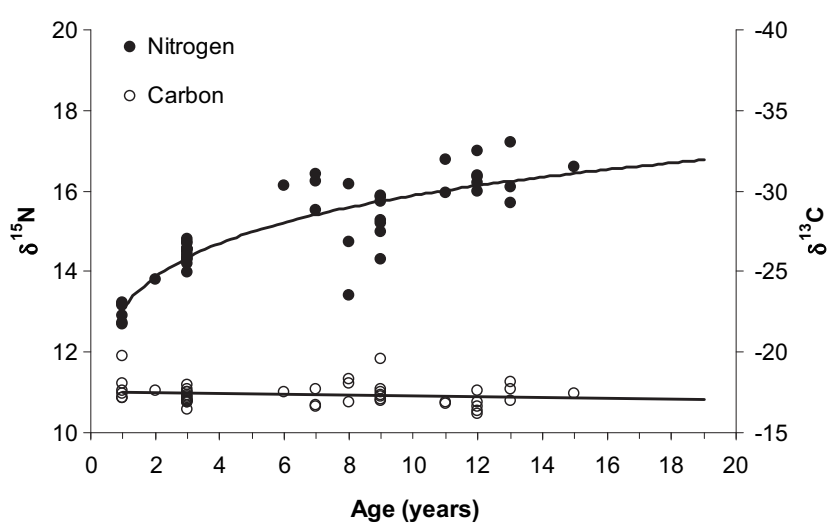

Fig. 6. $-\delta^{15} \mathrm{~N}$ and $\delta^{13} \mathrm{C}$ stable isotopes plotted against age of shorthorn sculpin from Peterhead Inlet and the Sylvia Grinnell River estuary, Nunavut.

power fitted regression demonstrated a strong correlation between $\delta^{15} \mathrm{~N}$ and age $\left(\delta^{15} \mathrm{~N}=13.08 \text { (age }\right)^{0.085}$, $\left.\mathrm{r}^{2}=0.77, \mathrm{p}<0.05\right)$. No significant linear relationship $\left(r^{2}=0.02, p>0.05\right)$ was detected between $\delta^{13} \mathrm{C}$ and age classes (Fig. 6). There was a significant correlation between $\delta^{15} \mathrm{~N}$ and the number of parasites in a shorthorn sculpin $(r=0.74, p<0.05)$ and a weaker correlation between $\delta^{13} \mathrm{C}$ and the number of parasites $(\mathrm{r}=$ $0.24, \mathrm{p}<0.05)$.

\section{DISCUSSION}

S horthorn sculpin in this study fed mainly on amphipods and can be contrasted with the report of Scott \& Scott (1988) where diets consisted of crabs, shrimps, sea urchin, gobies, small cod, and marine worms and possibly herring. Moore \& Moore 1974) found shorthorn sculpin in the Cumberland Sound area of Baffin Island fed heavily on benthic gastropods, Littorina saxatilis (Olivi, 1792) and Margarites umbilicalis
(Broderip \& Sowerby, 1829, the bivalve, Modiolaria discors L. 1767. According to Moore \& Moore (1974) shorthorn sculpin, under limited illumination, fed on brightly coloured plankton. Undoubtedly shorthorn sculpin are opportunistic generalist feeders in the bentholittoral zone but there must be some diet selection as there is little overlap in the diet between shorthorn sculpin and anadromous Arctic char diets (Dick \& Gallagher, 2007) even though both species of fish frequented the intertidal zone in the study area. The amphipods G. setosus and O. litoralis were important diet items of shorthorn sculpin in the study area (Table I). Diet items such as Arctic cod and polychaetes occurred less frequently but were more common in stomachs of older individuals.

Fourteen metazoan species of parasites were recovered from the shorthorn sculpin and this data can be compared to the list provided by Macdonald \& Margolis (1995) where 13 metazoan parasitic species, five of which were annelids. Brachyphallus crenatus (Rudolphi 1802) Odhner, 1905, Lepidapedon rachion (Cobold, 1858) Stafford, 1904, Hemiuridae sp., B. sturionus, E. gadi, Corynosoma strumosum (Rudolphi, 1802) and Capillaria sp. appear to be new host records for North America. E. gadi and the ascarid Hysterothylacium aduncum (Rudolphi, 1802) were reported from shorthorn sculpin from the south-east Baltic by Sulgostowska et al. (1990). The presence of the ascarid larval nematodes in the shorthorn sculpin has been reported by Jensen \& Andersen (1992), Jensen (1997) and Midtgaard et al. (2003) discussed the transmission of $P$. decipiens from shorthorn sculpin to seals.

Most of the parasite species were transmitted through diet. For example, the crustacean Themisto libellula (Lichtenstein, 1822) transmits some of the most abundant parasites i.e, P. squamatus and B. sturionis. Capillaria sp. and E. gadi are transmitted by Gammarus sp. (Isinguzo \& Dick, unpublished data). B. crenatus is transmitted by Mysis oculata and M. mixta Lilljeborg, 1852 (Isinguzo \& Dick, unpublished data). An increase in number of parasite species with host age reflects a more diverse diet as shorthorn sculpin age (Fig. 2).

Similar to parasite results, shorthorn sculpin stable isotopes indicate that diet diversity increased with fish age. The high positive correlation $(r=0.74)$ between $\delta^{15} \mathrm{~N}$ and number of parasite species in a host suggests that the number of parasite species are a good predictor of diet diversity and when combined with stable isotopes values provide complementary data on trophic status. An increase in $\delta^{15} \mathrm{~N}$ values with age indicates that sculpin consumed diet items that were enriched in nitrogen. This enrichment did not produce a clear cut trophic shift as the change in $\delta^{15} \mathrm{~N}$ values are $<3.4 \%$ (Minagawa \& Wada, 1984). This is not surprising since amphipods dominate the diet. The importance of 
amphipods in the diet is also noted when isotope values are compared across age classes. Some older shorthorn sculpin had diets similar to one and three year old sculpin and an eight year old had a $\delta^{15} \mathrm{~N}$ value that overlapped with one-year-old shorthorn sculpin. Sculpin that were eight and nine years old also had $\delta^{15} \mathrm{~N}$ values similar to three year old shorthorn sculpin. Further support for a predominately benthic food source, such as amphipods, is supported by similar $\delta^{13} \mathrm{C}$ values across all size/age classes of shorthorn sculpin (Fig. 5). Older sculpin had diet items in addition to amphipods which had higher $\delta^{15} \mathrm{~N}$ values which resulted in a higher $\delta^{15} \mathrm{~N}$ signature. By contrast $\delta^{13} \mathrm{C}$ values of shorthorn sculpin are primarily based on $\delta^{13} \mathrm{C}$ values of three diet items ( $G$. setosus, O. litoralis and polychaetes). Interestingly, parasites were a better indicator of shorthorn sculpin feeding pattern than $\delta^{13} \mathrm{C}$ values as parasite richness was highly correlated with $\delta^{15} \mathrm{~N}$.

The high prevalence and intensities and concentration of $E$. gadi in the midgut were the impetus to investigate its impact on host condition. E. gadi has been reported at low prevalences and mean intensities of 13-20\% and 1-4, respectively in shorthorn sculpin from Hel (south-east Baltic) by Sulgostowska et al. (1990) and is compared to a prevalence of $88-100 \%$ and intensities of 28-35 in our study. Acanthocephalans are well known to have negative affects on fish (Nickol, 1986; Buchanan, 1986). Buchanan (1986) reported a negative correlation between the number of E. gadi and energy stores in Baltic cod (Gadus morhua L. 1758) and others (Bakker \& Mudelin, 1999; Sasal et al., 2001) reported that acanthocephalans have an adverse affect on the fitness of the fish host. E. gadi did not affect condition or reproduction of shorthorn sculpin in Frobisher Bay, although relative liver weight was smaller in males with high infections (Table III). Sasal et al. (2001) reported that Acanthocephaloides propinguus Dujardin, 1845 had negative effects on gonado-somatic index and egg production in female gobiid fish, Gobius bucchichi Steindachner 1870. By contrast, we were unable to show any impact of high parasite levels on the condition of shorthorn sculpin.

To summarize, the diet of the shorthorn sculpin is variable but two diet items, both amphipods species, dominated its diet between years and during the open water season. Amphipods in the diet were correlated with parasite numbers and more parasite species in older larger sculpin indicates that diet diversity increased with host size. Similarly stable isotope values for $\delta^{15} \mathrm{~N}$ increased with age/size indicating that collectively these diet items have an overall higher $\delta^{15} \mathrm{~N}$ signature, even though the dominant food items did not change. By contrast, the $\delta^{13} \mathrm{C}$ signature of dominant diet items mask the $\delta^{13} \mathrm{C}$ values of minor diet items. Clearly, parasites and stable isotope values provide complementary data on feeding patterns of shorthorn sculpin.

\section{ACKNOWLEDGEMENTS}

W e thank Jason Carpenter (senior instructor) and the second year class of the Environmental Technology Program (2005) at Nunavut Arctic College, Iqaluit, for assistance with some of the collections. We also thank the Nunavut Research Institute for providing a base from which to work while in Iqaluit. T. Dick gratefully acknowledges research support through an NSERC Northern Research Chair and C. Chambers acknowledges financial support from an NSERC Northern Traineeship.

\section{REFERENCES}

BAKker T.C.M. \& Mundwiler B. Pectoral fin size in a fish species with paternal care: condition-dependent sexual trait revealing infection status. Freshwater Biology, 1999, 41, 543-551.

Buchanan K. On the infection of the Baltic cod (Gadus morbua) by the acanthocephalan Echinorbynchus gadi (Zoega) Muller. Nordisk veterinaermedicin, 1986, 38, 308314.

CARE. Manual on generalized age determination: procedures for groundfish. Committee of Age Reading Experts. Canada/ U.S. Groundfish Committee, Seattle, 2006.

CORTÉs E. A critical review of methods of studying fish feeding based on analysis of stomach contents: application to elasmobranch fishes. Canadian Journal of Fisheries and Aquatic Sciences, 1997, 54, 726-738.

DAvenport S. R. \& BAX N. J. A trophic study of a marine ecosystem off southeastern Australia using stable isotopes of carbon and nitrogen. Canadian Journal of Fisheries and Aquatic Sciences, 2002, 59, 514-530.

Dick T.A. \& Gallagher C.P. Arctic aquatic ecosystem research: present and future. Meridian, 2007, Canadian Polar Commission, Spring/Summer: 9-14.

ENNIS G.P. Age, growth and sexual maturity of the shorthorn sculpin, Myoxocephalus scorpius, in Newfoundland waters. Journal of the Fisheries Research Board of Canada, 1970, 27, 2155-2158.

JENSEN T. Experimental infection/transmission of sculpins (Myoxocephalus scorpius) and cod (Gadus morbua) by sealworm (Pseudoterranova decipiens) larvae. Parasitology Research, 1997, 83, 380-382.

Jensen T. \& ANDERSEn K. The importance of sculpin (Myoxocephalus scorpius) as intermediate host and transmitter of the sealworm Pseudoterranova decipiens. International Journal of Parasitology, 1992, 22, 665-668.

Johnson M. W., Hesslein R.H. \& Dick T.A. Host length, age, diet, parasites and stable isotopes as predictors of yellow perch, (Perca flavescens Mitchill), trophic status in nutrient poor Canadian Shield lakes. Environmental Biology of Fishes, 2004, 71 (4), 379-388.

Kline T.C Jr., Wilson W.J. \& Goering J.J. Natural isotope indicators of fish migration at Prudhoe Bay, Alaska. Canadian Journal of Aquatic Sciences, 1998, 55, 1494-1502. 
Macdonald T.E. \& Margolis L. Synopsis of the parasites of fishes of Canada: Supplement (1978-1993). Canadian Special Publication of Fisheries and Aquatic Sciences, 1995, 122.

Margolis L., Esch G.W., Holmes J.C., Kuris A.M. \& Schad G.A. The use of ecological terms in parasitology: report of an ad hoc committee of the American Society of Parasitologists. Journal of Parasitology, 1982, 68, 131-133.

Michener R.H. \& Kaufman L.S. Stable isotope ratios as tracers in marine food webs: an update. Chapter 9, in: Stable Isotopes in Ecology and Environmental Science. Lajtha K. \& Michener R.H. (eds), Blackwell Scientific, Boston, 2007, 238-282.

Midtgaard T., Andersen K. \& Halvorsen O. Population dynamics of sealworm, Pseudoterranova decipiens sensu lato, in sculpins, Myoxocephalus scorpius, from two areas in Norway between 1990 and 1996. Parasitology Research, 2003, 89, 387-392.

Minagawa M. \& Wada E. Stepwise enrichment of ${ }^{15} \mathrm{~N}$ along food chains: further evidence and the relation between $\delta^{15} \mathrm{~N}$ and animal age. Geochimica et Cosmochimica Acta, 1984, 48, 1135-1140.

Monteiro P.M.S., James A.G., Sholto-Douglas A.D. \& Field J.G. The $\delta^{13} \mathrm{C}$ trophic position isotope spectrum as a tool to define and quantify carbon pathways in marine food webs. Marine Ecology Progress Series, 1991, 78, 33-40.

Moore I.A. \& Moore J.W. Food of shorthorn sculpin, Myoxocephalus scorpius, in the Cumberland Sound area of Baffin Island. Journal of the Fisheries Research Board of Canada, 1974, 31, 355-359.

Nickol B.B. Phylum Acanthocephalla, in: Fish Diseases and Disorders. Woo P. (ed.), $2^{\text {nd }}$ Edition, CAB International, United Kingdom, 2006, 444-465.

Norderhaug K.M., Christie H., Fossa J.H. \& Fredriksen S. Fishmacrofauna interactions in a kelp (Laminaria byperborean) forest. Journal Marine Biological Association of the United Kingdom, 2005, 185, 1279-1286.

Peterson B.J. \& Fry B. Stable isotopes in ecosystem studies. Annual Review of Ecology and Systematics, 1987, 18, 293320.

Pinnegar J.K. \& Polunin N.V.C. Contributions of stable-isotope data to elucidating food webs of Mediterranean rocky littoral fishes. Oecologia, 2000, 122, 399-409.

Post D.M. Using stable isotopes to estimate trophic position: models, methods and assumptions. Ecology, 2002, 83 (3), 703-718.

RICKER W.E. Computation and interpretation of biological statistics of fish populations. Bulletin of the Fisheries Research Board of Canada, 1975, 191.

Sasal P., Faliex E., De Buron I. \& Morand S. Sex discrimatory effect of the acanthocephalan Acanthocephaloides propinquus on a gobiid fish Gobius bucchichii. Parasite, 2001, 8, 231-236.

Scotт W.B. \& Scotт M.G. Atlantic Fishes of Canada. Canadian Bulletin of Fisheries and Aquatic Sciences, 1988, 219.

Sholto-Douglas A.D., Field J.G., James A.G. \& van Der Merwe N.J. ${ }^{13} \mathrm{C} /{ }^{12} \mathrm{C}$ and ${ }^{15} \mathrm{~N} /{ }^{14} \mathrm{~N}$ isotope ratios in the Southern Benguela ecosystem: indicators of food web relationships among different size-classes of plankton and pelagic fish; differences between fish muscle and bone collagen tissues. Marine Ecology Progress Series, 1991, 78, 23-31.

Sulgostowaska T., Jerzewska B. \& Wicikowski J. Parasite fauna of Myoxocephalus scorpius (L.) and Zoarces viviparus (L.) from environs of Hel (south-east Baltic) and seasonal occurrence of parasites. Acta Parasitologica Polonica, 1990, 35, 143-148.

Thomas C.J. \& Cahoon L.B. Stable isotope analyses differentiate between different trophic pathways supporting rockyreef fishes. Marine Ecology Progress Series, 1993, 95, 1924.

Wainright S.C., Fogarty M.J., Greenfield R.C. \& Fry B. Longterm changes in the Georges Bank food web: trends in stable isotope compositions of fish scales. Marine Biology, 1993, 115, 481-493.

Reçu le 12 mai 2009 Accepté le 10 septembre 2009 